\title{
STUDIES ON THE TRADITIONAL METHODS OF PRODUCTION OF MAIZE TUWO (A NIGERIAN NON-FERMENTED MAIZE DUMPLING)
}

\section{Bolade MK $^{* 1}$, Adeyemi IA ${ }^{2}$ and AO Ogunsua ${ }^{1}$}

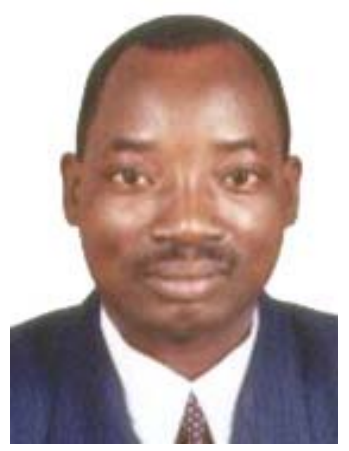

Bolade Mathew

*Corresponding author-Email: matbolade@yahoo.co.uk

${ }^{1}$ Department of Food Science and Technology, Federal University of Technology, P.M.B. 704, Akure, Ondo State, Nigeria.

${ }^{2}$ Department of Food Science and Engineering, Ladoke Akintola University of Technology, P.M.B. 4000, Ogbomoso, Oyo State, Nigeria. 


\section{ABSTRACT}

This study was carried out in order to identify the critical areas that could have potential influence on the quality characteristics of maize tuwo (a Nigerian nonfermented maize dumpling) and which might also serve as a basis for any technological improvement effort with respect to the product quality. Commercial producers of maize tuwo were interviewed and their production processes evaluated while samples (maize flour and tuwo) collected from them were respectively analyzed. The investigation revealed that white maize grains of different varieties were commonly being used for tuwo preparation and this has a potential of influencing product quality. The quality factors being used for assessing maize tuwo by the consumers were colour, texture (mouldability and swallowability) and taste. Other critical areas with potential influence on product quality were variation in flour production methods which are grit soaking and grit non-soaking methods and variation in particle size distribution of flour being used in tuwo preparation. Grit nonsoaking method was generally being adopted by most maize tuwo producers while the flour from grit soaking method was generally believed to give a better tuwo quality. Variation in the colour indices of maize flour samples was another critical area that could influence product quality. The lightness index ( $\mathrm{L}^{*}$-value) of the flour ranged between 88.2 and 88.9 while the chroma (C-value) ranged between 13.3 and 15 . There was also a variation in the softness index (textural quality) of maize tuwo. The softness index ranged between $17.8 \mathrm{~mm}$ and $18.7 \mathrm{~mm}$ immediately after cooling but ranged between $16.2 \mathrm{~mm}$ and $17.5 \mathrm{~mm}$ about nine hours after production. Another critical area that could influence tuwo quality was variation in flour/water ratios involved in product preparation. The ratio ranged between 1:3.3 and 1:3.8. The conclusion made from the ingredient standardization effort was that the overall flour/water ratio for maize tuwo preparation should be 1:3.5. The sequential mixing of flour and water during maize tuwo preparation should also be as follows: initial slurry preparation (20 and $25 \%$ of the desired total flour quantity and water volume, respectively), water used in initial boiling (60\% of total volume), flour added to the pap-like consistency ( $80 \%$ of total) and water added to the gel- like consistency (15\% of total volume).

Key words: Maize, tuwo, traditional, quality, dumpling 


\section{INTRODUCTION}

Maize (Zea mays L.) is an important cereal grain in Nigeria and the world at large. Its utilization includes food uses, for industrial processing as a raw material, and for animal feed formulation [1]. However, utilization of maize for food production is the most common in the developing countries as against industrial usage in the developed countries [2]. Maize tuwo is one of the food products that can be obtained from maize in Nigeria. It is essentially a food gel or dumpling which is stiff, has a yield value and can be moulded into shapes [3]. In addition, it does not flow under gravity and has moisture content in the range of $64-80 \%$ [4]. Other food products that can be obtained from maize, particularly in Nigeria, include ogi, eko or agidi, egbo, elekute, aadun, abari and guguru [5]. The production of most of the indigenous food products, particularly in the developing countries, has not progressed much beyond the traditional processing techniques due to a slow pace in technological innovations which is obviously aggravated by misplaced government policy initiatives on the importance of technology in industrialization [6,7]. Due to this poor state of technological advancement in traditional food processing, the processing methods are usually susceptible to problems of food loss, labour-intensive processing operations and possible poor quality end-product [8].

Maize tuwo is a food product indigenous to the Hausa-speaking communities in Nigeria and indeed the Hausa-speaking communities of the West Africa sub-region. The food product is normally prepared from non-fermented maize flour to form a food gel or dumpling. The preparation and consumption of maize tuwo have, however, spread to other non-Hausa-speaking communities as a result of inter-ethnotribal movement of people in the sub-region [9]. One major problem associated with maize tuwo is essentially that of textural and sensory quality inadequacies which are reflected in its inability to form highly elastic, long-bodied gel; its ability to retrograde easily when cooled; and its tendency to brittle easily when moulded with hand during meal consumption thereby creating an unsatisfactory psychological enjoyment. These associated problems with maize tuwo have made the product unappealing to people particularly from non-Hausa-speaking communities while various efforts are also being made by the traditional consumers of the product to ameliorate these textural and sensory problems within the confine of their indigenous technologies. Examples of such local practices include the use of cassava flour to form a composite with maize flour. Similarly, the traditional consumers themselves normally consume the product while hot or warm in order to circumvent the textural and sensory problems that may ensue when the product gets cooled [9]. It has been observed that the quality and general acceptability of a cereal product is usually influenced by the physical and chemical properties of the cereal from which it is produced [10]. These properties may be modified through chemical, physical and enzymic processes so as to obtain desired functional characteristics [11].

A few attempts have been made by researchers to improve the textural and sensory quality inadequacy of maize tuwo. The influence of hydrothermal treatment of maize grains on the textural quality and general acceptability of the product was one of such

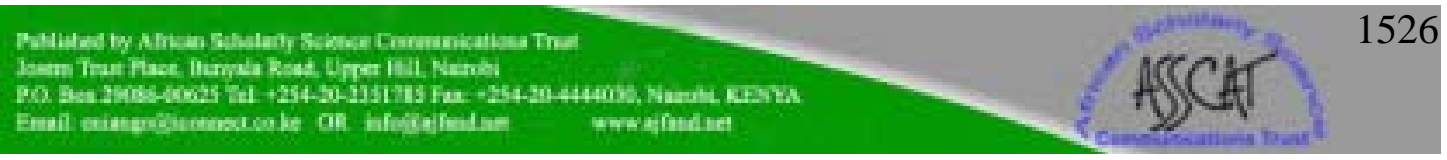


attempts [9]. It has been suggested, however, that any quality improvement effort made to a traditional food product should be carried out in such a way that the upgraded technologies could easily be integrated into the food processing system and should result in improved product quality and reduced drudgery without upsetting the social structure [12]. Furthermore, such a new technology is expected to be accessible, affordable, environment-friendly and tailored to meet the peculiar and cultural norms of the people [13].

Therefore, in order to establish a basis for any technological improvement effort on the textural and sensory quality inadequacies of maize tuwo, there is the need to examine the totality of its traditional processing methods as well as consumers' perception of its acceptability with a view to identifying the critical areas of the production process that have potential influence on the product quality attributes; and this is the general objective of this study.

\section{MATERIALS \& METHODS}

\section{Sources of materials}

Four different commercial producers of maize tuwo (all women) were named Producers I, II, III and IV; located at Akure (Ondo State), Ojoo-Ibadan (Oyo State), Saabo-Ibadan1 (Oyo State), and Saabo-Ibadan2 (Oyo State) respectively, in Nigeria. Materials collected from each producer were maize flour, fresh maize tuwo and remnant market maize tuwo, about $9 \mathrm{hr}$ after production.

\section{Interview of commercial producers of maize tuwo}

Each identified producer of maize tuwo was interviewed with respect to the types of maize varieties being used in tuwo production, procedures for flour preparation, methods of tuwo preparation, mode of sale of the product, quality indices for the assessment of the product and period of the day at which the product is commonly consumed.

\section{Determination of particle size distribution of maize flour samples}

The particle size distribution of maize flour samples obtained from the commercial tuwo producers was respectively carried out using a sieve analysis technique with the aid of Endecotts Test Sieve Shaker (model 1 MK11-11381, London, UK) as described by Bolade and Buraimoh [14]. Different sieves with varying apertures (i.e. 63, 150, 300,425 and $850 \mu \mathrm{m}$ ) were arranged on top of each other with the one having the biggest aperture on the topmost level and then arranged in decreasing order of aperture. The sieves were fastened into a rigid position using a fastening screw after a standard quantity of the flour sample $(250 \mathrm{~g})$ was already placed inside the topmost sieve. The sieve shaker was then switched on for $10 \mathrm{~min}$ after which the quantity of flour retained on each sieve was collected and weighed.

\section{Colour measurement}

The colour of maize flour and tuwo samples was measured using a colour measuring instrument (model SN 3000421, ColorTec-PCM, USA) and the values expressed on

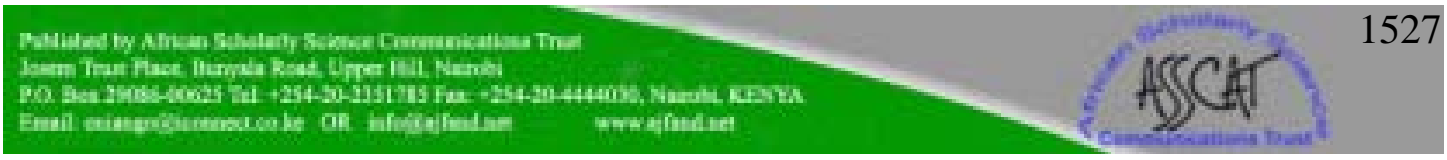


the $\mathrm{L}^{*}, \mathrm{a}^{*}, \mathrm{~b}^{*}$ tristimulus scale. The $\mathrm{L}^{*}$-value represents the lightness index; $\mathrm{a}^{*}$-value represents the degree of redness $\left(-a^{*}\right)$ or greenness $\left(+a^{*}\right)$; and $b^{*}$-value represents the degree of yellowness $\left(-b^{*}\right)$ or blueness $\left(+b^{*}\right)$. The instrument was initially standardized $\left(\mathrm{L}^{*}=90.29, \mathrm{a}^{*}=1.37, \mathrm{~b}^{*}=0.06\right)$ using a white reference standard (white duplicating paper sheet, $80 \mathrm{~g} / \mathrm{m}^{2}$ ). The results from three replicates per sample were averaged. The colour purity, expressed as Chroma (C), was calculated from $\left(a^{2}+b^{2}\right)^{1 / 2}$, where zero value represents black and 100 represents white. The hue angle $\left(h^{\circ}\right)$ represents colour by a positive number between $0^{\circ}$ and $360^{\circ}$, where $0^{\circ}=$ reddishpurple, $90^{\circ}=$ yellow, $180^{\circ}=$ bluish-green, and $270^{\circ}=$ blue; and it is essentially a measurement of angular deviation of sample colour from three primary colours of red, yellow and green. One of the following equations was used to calculate the hue angle: if $a>0$ and $b>0$, then $h^{0}=\tan ^{-1}(b / a)$; if $a<0$ and $b>0$, then $h^{0}=\left[\tan ^{-1}(b / a)\right]+180^{\circ}$; if a $>0$ and $\mathrm{b}<0$, then $\mathrm{h}^{\mathrm{o}}=\left[\tan ^{-1}(\mathrm{~b} / \mathrm{a})\right]+360[15,16]$.

\section{Evaluation of softness index of maize tuwo samples}

The softness indexes of maize tuwo samples were determined using Precision Cone Penetrometer (Benchtop model, Pioden Controls Ltd., Canterbury, UK). For each maize tuwo sample, a quantity was scooped from the whole chunk using an openended cylindrical container (tin of milk) so that the structural make-up of the product was not adversely affected. The scooped quantity was then transferred into the standard cup attached to the penetrometer and the centre of the cup positioned perpendicularly to the falling probe of the penetrometer. The probe was finally released to fall freely from a standard distance to penetrate into the product in the cup. The total depth of penetration of the probe was then read on the penetrometer scale and the reading, expressed in millimeter $(\mathrm{mm})$, was taken as an index of the product softness.

\section{Determination of microbial status of commercial maize tuwo}

The total bacterial and fungal counts in the commercial maize tuwo samples (about 9 hr after production) were evaluated using pour plate techniques [17]. Some quantities of the sample were first comminuted followed by suspension of one gram of this comminuted sample in $10 \mathrm{ml}$ of $0.1 \%$ peptone water and shaken continually for 30 minutes to ensure uniform suspension of organisms. Decimal dilutions of the suspension in $0.1 \%$ peptone water were carried out up to $10^{-4}$. One millilitre $(1 \mathrm{ml})$ and $0.1 \mathrm{ml}$ each from $10^{-2}$ and $10^{-4}$ dilutions respectively were then inoculated on nutrient agar contained in separate duplicate petri dishes and another $1 \mathrm{ml}$ and $0.1 \mathrm{ml}$ on acidified potato dextrose agar (PDA) in separate duplicate petri dishes. The nutrient agar plates were incubated at $37^{\circ} \mathrm{C} \pm 2^{\circ} \mathrm{C}$ for up to $24 \mathrm{hr}$ while the potato dextrose agar plates were incubated at room temperature for up to $48 \mathrm{hr}$. The formed bacterial colonies were counted from the nutrient agar plates while fungal colonies were counted from the potato dextrose agar plates using a colony counter (model GNW-330-010X, Gallenkamp, England). 


\section{Evaluation of ingredient utilization (overall flour/water ratio) in maize tuwo preparation}

The four different commercial producers of maize tuwo were individually engaged to prepare the product using freshly milled flour (9.2\% moisture content; Shagari local maize variety). In the course of preparing the product, such parameters as flour proportion and water quantity involved during sequential mixing were measured. Other parameters measured were the overall cooking time and the overall flour/water ratio. The data generated here served as a basis for the standardization of preparation procedure for maize tuwo.

\section{Standardization of flour/water ratio involved in the production of maize tuwo}

Different ratios of flour to water (w/v) used in the preparation of maize tuwo were investigated. The ratios chosen were 1:3.1, 1:3.3, 1:3.5, 1:3.7, and 1:3.9; based on the observation made in the commercial practice. The five tuwo samples obtained after the preparation were then subjected to sensory evaluation after cooling while they were similarly evaluated for degree of softness using Precision Cone Penetrometer (Benchtop model, Pioden Controls Ltd., Canterbury, UK).

\section{Sensory evaluation}

Maize tuwo samples prepared from different overall flour/water ratios were evaluated for their sensory qualities and general acceptability. A scoring test was used which was designed to determine which of the products was most preferred. A 20-member taste panel was requested to carry out the rating of tuwo samples. The panelists were all familiar with the traditional product while they were also instructed on the use of sensory evaluation procedures. Each of the panelists was asked to rate the samples on the basis of colour, taste, aroma, texture (mouldability) and overall acceptability using a nine-point hedonic scale $(9=$ like extremely; $5=$ neither like nor dislike; $1=$ dislike extremely). The scores from the rating were subsequently analyzed $[18,19]$.

\section{Statistical analyses}

All determinations reported in this study were carried out in triplicates. In each case, a mean value and standard deviation were calculated. Analysis of Variance (ANOVA) was also performed and separation of the mean values was by Duncan's Multiple Range Test at $\mathrm{P}<0.05$ using Statistical Package for Social Sciences (SPSS) software, version 10.0.

\section{RESULTS}

\section{General information from the commercial production process of maize tuwo}

The general information pertaining to the commercial production process of maize tuwo is presented in Table 1. All the four commercial producers of maize tuwo were using white maize grains for their respective production processes. The local maize variety being used by the commercial tuwo producers also varied and this includes Killa, Agbado-oko, and Shagari varieties. Hawking of the food product was found to be the most common mode of sale among the commercial producers except for

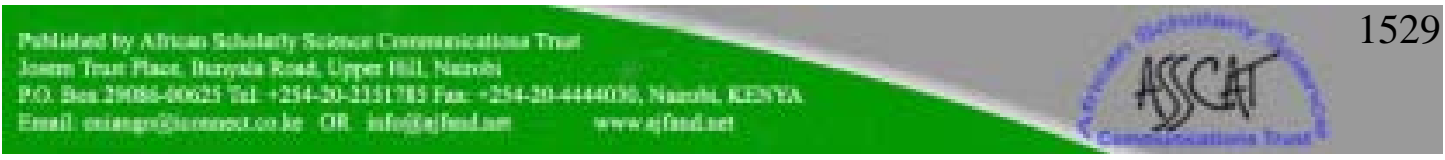


Producer III (Saabo-Ibadan1) who was using a canteen as a selling point. The customers of the canteen at Saabo-Ibadan1 were noted to be medium-income earners.

All the commercial producers of maize tuwo agreed that certain quality factors were being used for assessing the product and these are colour (white to creamy), texture (ease of mouldability and swallowability) and pleasant taste (cooked maizy taste). The food product was usually being consumed for lunch and/or dinner while the method of maize flour production commonly used by the commercial tuwo producers was grit non-soaking method as against the grit soaking method.

\section{Maize flour and tuwo preparation procedures}

The production procedures of flour meant for maize tuwo preparation are presented in Fig. 1. The two flour production methods (grit non-soaking and grit soaking methods) had common initial unit operations which were cleaning, tempering, and decortication to obtain the maize grits. The grits were then milled using a plate mill and sieved to obtain the ultimate flour, and this represents the grit non-soaking method. The grit soaking method involved soaking of the maize grits for 2-3 hours, draining of water, sun-drying of wet grits for 1-2 days depending on weather conditions, milling of dried grits to flour and sieving to obtain the ultimate flour.

The commercial preparation procedure for maize tuwo is presented in Fig. 2. It involved initial slurry preparation by mixing appropriate quantities of maize flour and water. The slurry was then poured into an appropriate quantity of boiling water and stirred properly to form a pap-like consistency. This was followed by addition of an appropriate quantity of maize flour to the pap-like consistency coupled with vigorous stirring to form a gel-like consistency. Subsequent unit operations include addition of small quantity of water to the gel-like consistency, leaving of the gel to cook for 5-7 min with the cooking pot covered and without stirring, after which a final stirring was made to obtain hot maize tuwo. Moulding into spherical or ball-like shape and cooling normally came last particularly in commercial preparation procedure. 


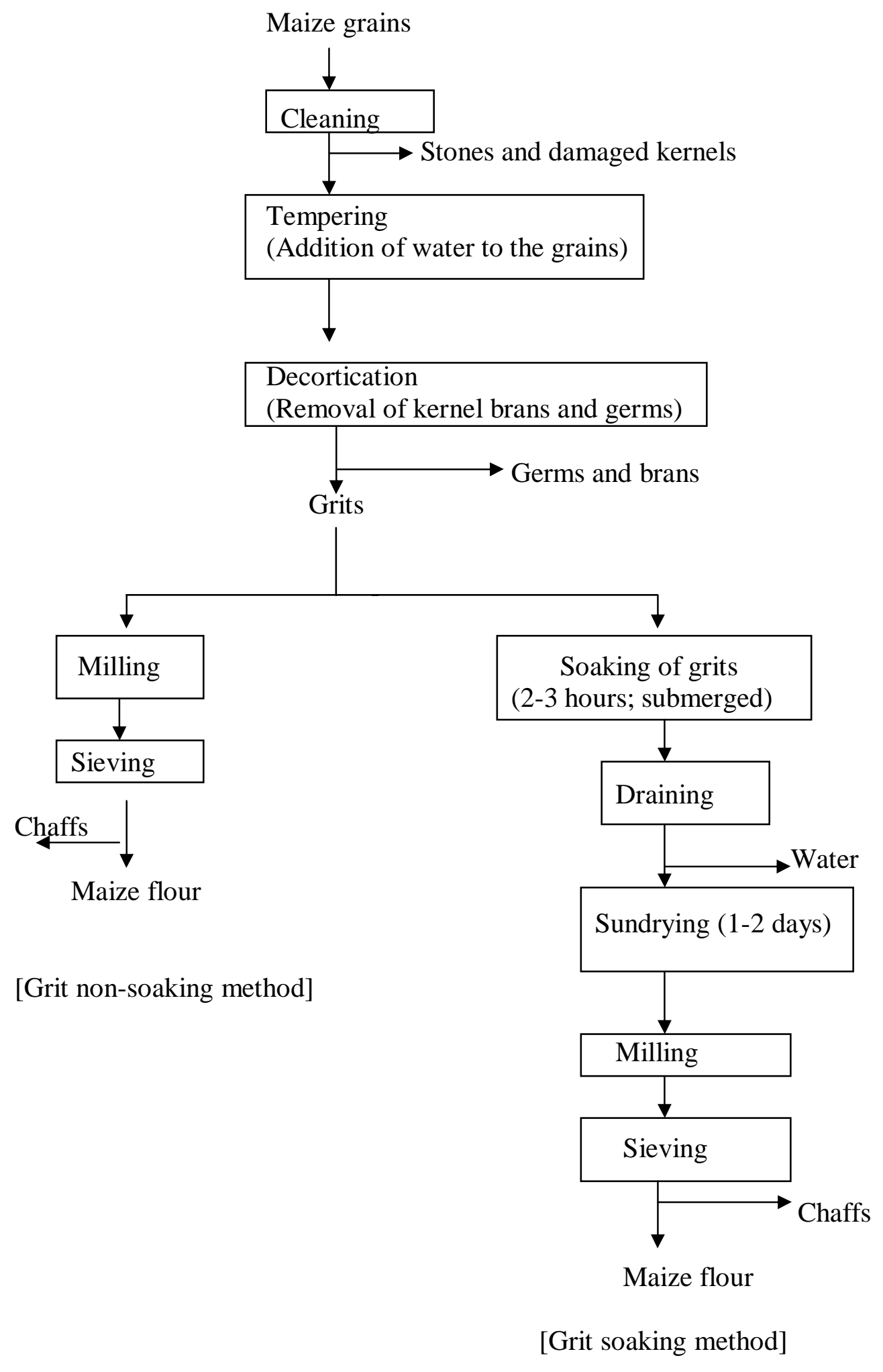

Figure 1: Production methods of maize flour meant for tuwo preparation 


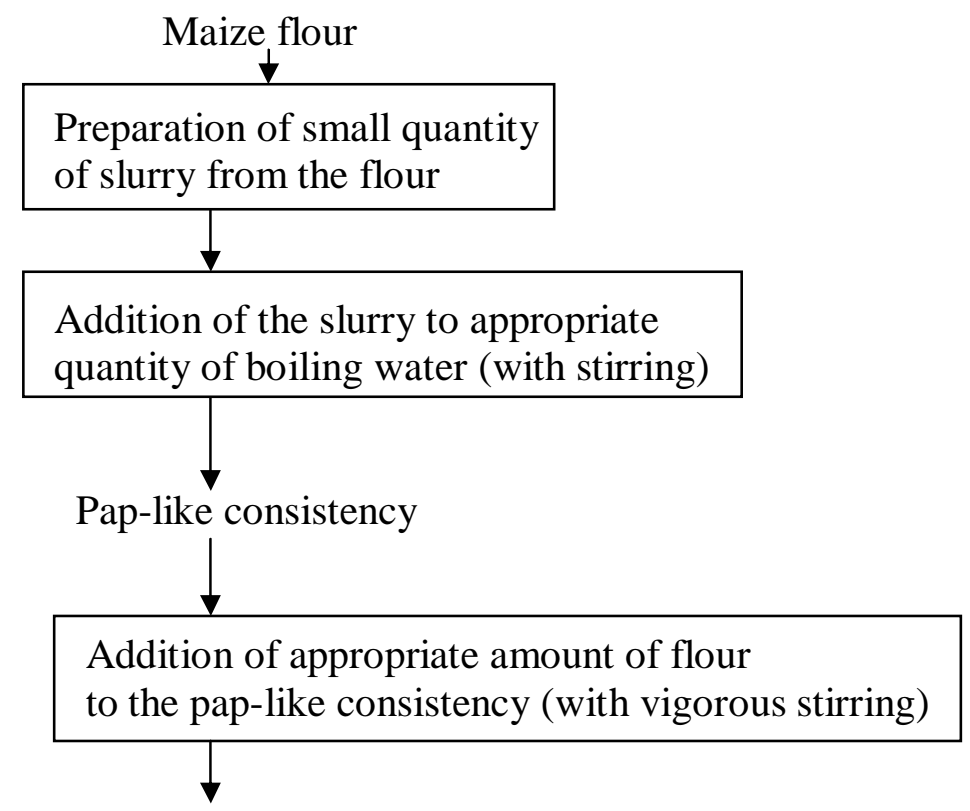

Gel-like consistency

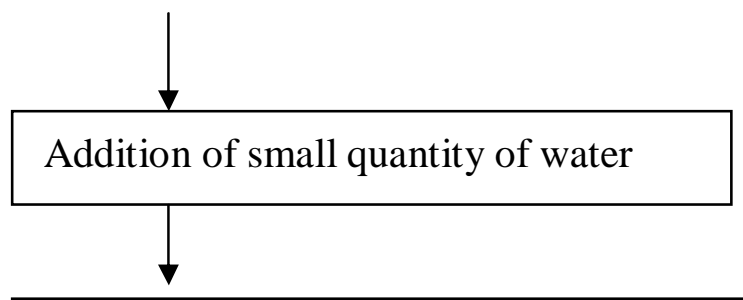

Cooking for 5-7 min, covered and without stirring

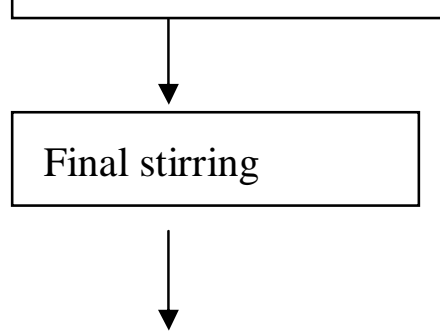

Hot maize tuwo

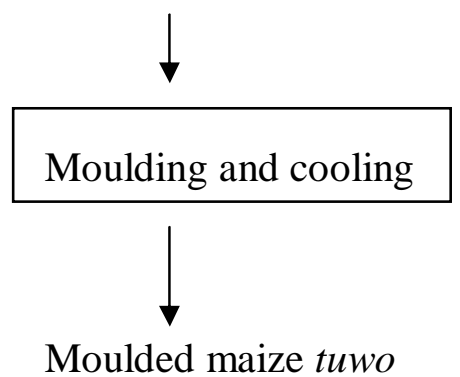

Figure 2: Commercial preparation procedure for maize tuwo 
Particle size distribution of maize flour and colour indices of flour and tuwo

The particle size distribution of maize flour samples obtained from the commercial tuwo producers is presented in Table 2. There was a variation in the particle size composition of the flour samples and this is reflected in different percentages of various particle sizes in flour samples from different producers. Flour sample from Producer I contained 23.4, 31.7 and $20.8 \%$ of particle size of 150,300 and $425 \mu \mathrm{m}$, respectively while that of Producer IV also contained 24.1, 37.9 and $16.9 \%$ of the particle size, respectively.

The colour of both maize flour and tuwo samples collected from the commercial tuwo producers is also shown in Table 2 . The $\mathrm{L}^{*}$-value (lightness index) of the flour ranged between 88.2 (Producer II) and 88.9 (Producer IV) while that of maize tuwo samples ranged between 66.6 (Producer II) and 67.4 (Producer IV); and these values were significantly different at $\mathrm{P}<0.05$. The chroma, $\mathrm{C}$-value, of the flour samples ranged between 13.3 and 15 while that of tuwo samples ranged between 8.6 and 9.2; and the values were also significantly different at $\mathrm{P}<0.05$. The hue angle, $\mathrm{h}^{\circ}$, of the flour samples ranged between 90.3 and 90.5 with no significant difference at $\mathrm{P}<0.05$ while that of maize tuwo samples ranged between 99.1 and 103.4 with a significant difference at $\mathrm{P}<0.05$.

\section{Microbial status and textural quality of commercial maize tuwo}

The microbial status and softness index of maize tuwo from various producers are shown in Table 3. The bacterial count in tuwo from the producers, about $9 \mathrm{hr}$ after production, ranged from $1.0 \times 10^{4}$ to $8.0 \times 10^{4}$-cfu/g with samples from Producers II and I having the lowest and highest values respectively. Most of the tuwo samples did not contain fungi except sample from Producer I with yeast and mould count of $1.0 \times 10^{2}$ $\mathrm{sfu} / \mathrm{g}$.

The softness index of market maize tuwo immediately after cooling and at about $9 \mathrm{hr}$ after production revealed that there was generally a reduction in the softness index of the product as post-production period extended (Table 3). The softness index of the product immediately after cooling ranged from 17.8 to $18.7 \mathrm{~mm}$ while, after about $9 \mathrm{hr}$ of production, it ranged from 16.2 to $17.5 \mathrm{~mm}$. Tuwo sample from Producer I had the lowest softness index $(17.8 \mathrm{~mm})$ immediately after cooling while that from Producer III was the highest $(18.7 \mathrm{~mm})$. However, tuwo sample from Producer I also had the lowest softness index $(16.2 \mathrm{~mm})$ about $9 \mathrm{hr}$ after production while that from Producer IV was the highest $(17.5 \mathrm{~mm})$.

\section{Standardization of ingredient utilization for the production of maize tuwo}

The ingredient utilization (flour and water) in the course of maize tuwo preparation, as illustrated in Fig. 2, is presented in Table 4. The amount of flour used in slurry preparation ranged from 19 to $22 \%$ while the quantity of flour added to the pap-like consistency in the course of tuwo preparation ranged from 78 to $81 \%$. Similarly, the quantity of water used in slurry preparation, initial boiling, and that added to the gellike consistency in the course of tuwo preparation ranged from 24.3 to $25.1 \%, 59$ to $62 \%$ and 12.9 to $16.4 \%$, respectively. The overall ratio of flour/water involved in tuwo

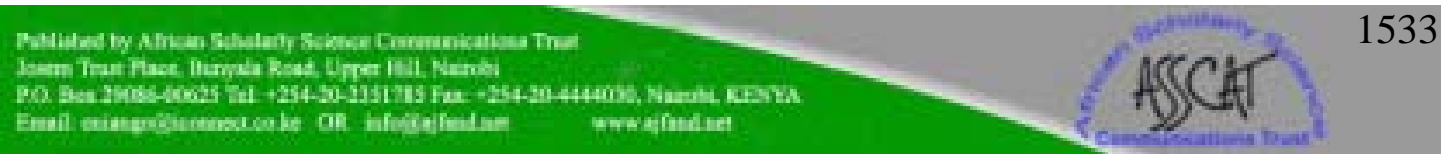


preparation was found to range from 1:3.3 to 1:3.8 while the total cooking time ranged from 30 to 33 min with respect to the quantity of final tuwo desired.

Different overall flour/water ratios were subsequently subjected to further evaluation and Table 5 shows the sensory quality rating and softness index of maize tuwo prepared from such different overall flour/water ratios. Tuwo sample with flour/water ratio of 1:3.5 was rated highest in all the sensory attributes, which include the colour, texture (ease of mouldability), aroma, taste and overall acceptability. This tuwo sample, however, was not significantly different $(\mathrm{P}<0.05)$ from Sample II (flour/water ratio of 1:3.3) in terms of colour and texture (ease of mouldability) and also from Sample V (flour/water ratio of 1:3.9) in terms of colour.

The softness index of tuwo samples prepared from different overall flour/water ratios ranged from 15.3 to $19.1 \mathrm{~mm}$ (Table 5). The tuwo sample with the highest sensory quality rating (Sample III) had a softness index value of $16.9 \mathrm{~mm}$. The regression curve of flour/water ratios and the softness index of maize tuwo samples and their sensory quality ratings, as shown in Fig. 3, revealed a linear relationship $(y=0.93 \mathrm{x}+$ $14.29 ; R^{2}=0.9909$ ) between the flour/water ratios and the softness indexes while a non-linear relationships (polynomial of third order) existed between the ratios and the sensory quality ratings of tuwo samples. Almost all the curves for the sensory factors converged at the point of flour/water ratio of 1:3.5 with corresponding highest sensory quality ratings.

\section{DISCUSSION}

\section{General information from the commercial production process of maize tuwo}

The use of white maize grains of different local varieties in the commercial production process of maize tuwo could be attributed to the age-long cultural practice of the traditional consumers (Hausa-speaking communities) coupled with the cultural belief that white maize grain is the most suitable variety for the production of such traditional dishes as tuwo, ogi, akamu, and eko [20]. However, recent happenings among the household consumers of the traditional food products have shown that the use of yellow maize grain for tuwo production is gradually creeping in simply for the sake of meal variety. Therefore, the involvement of different local maize varieties in the production of maize tuwo is a critical area that may have a potential influence on the product quality. Varieties of food crops have been observed to influence the quality characteristics of food products derived from such crops [21, 22]. Hawking, as a mode of product sale, was most common among the commercial maize tuwo producers and this trend could be attributed to the fact that the food product is generally regarded as one of the cheapest sources of daily calorie that could be afforded by low-income earners, hence the need to hawk the product among them for a possible high turnover. The commercial maize tuwo producers whose selling modes were through hawking could only produce for lunch as the target-consumers could only be available in the afternoon. 


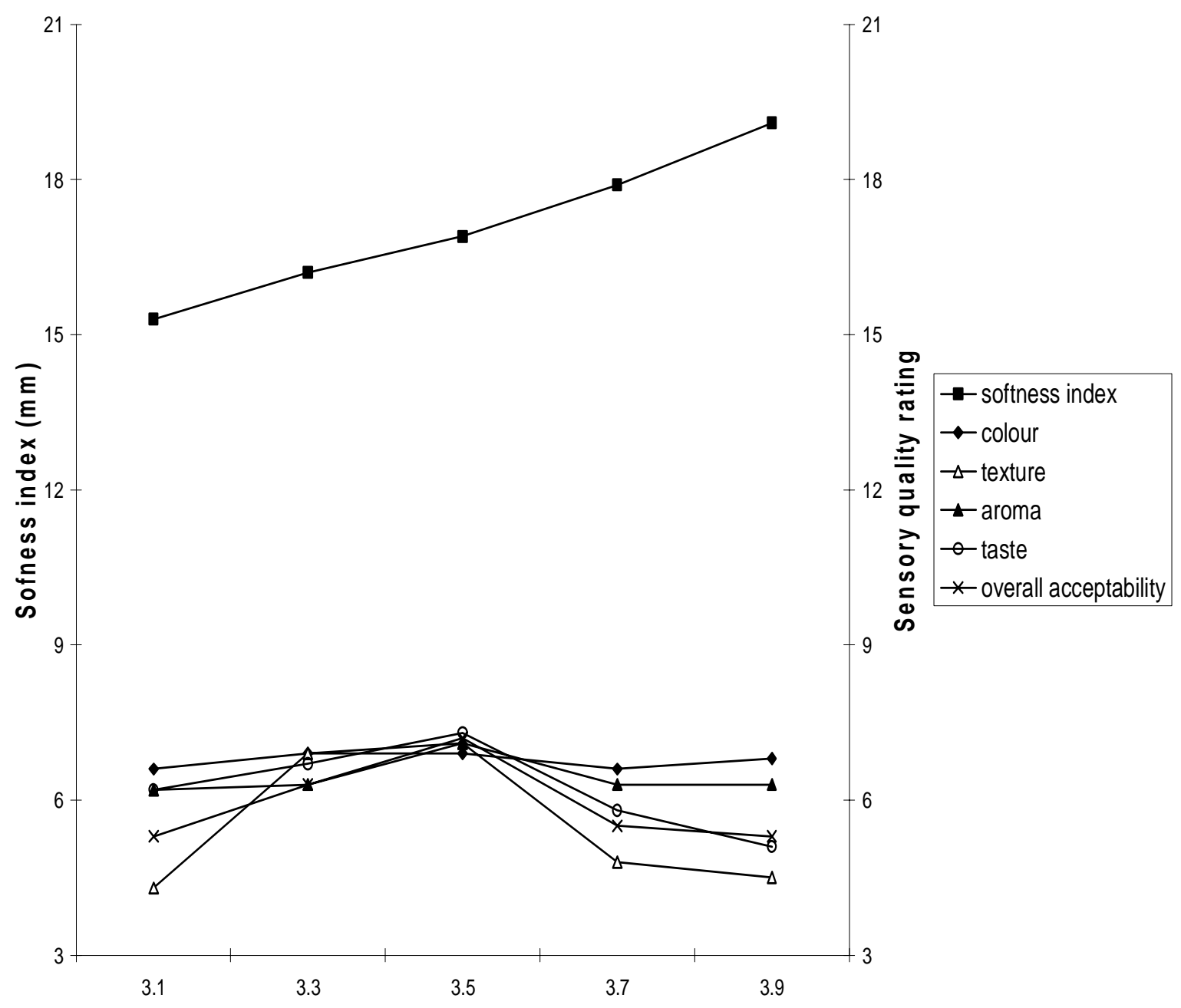

Flour/water ratio

Curve equations:

Softness index: $\quad \mathrm{y}=0.93 \mathrm{x}+14.29 ; \quad \mathrm{R}^{2}=0.9909$

Colour: $\quad \mathrm{y}=0.0667 \mathrm{x}^{3}-0.6357 \mathrm{x}^{2}+1.7976 \mathrm{x}+5.36 ; \quad \mathrm{R}^{2}=0.9006$

Texture: $\quad \mathrm{y}=0.3667 \mathrm{x}^{3}-3.0920 \mathrm{x}^{2}+12.04 \mathrm{x}-4.28 ; \quad \mathrm{R}^{2}=0.9594$

Aroma: $\quad \mathrm{y}=0.0083 \mathrm{x}^{3}-0.2036 \mathrm{x}^{2}+0.9881 \mathrm{x}+5.34 ; \quad \mathrm{R}^{2}=0.4283$

Taste: $\quad \mathrm{y}=0.0583 \mathrm{x}^{3}-0.8464 \mathrm{x}^{2}+2.9952 \mathrm{x}+3.92 ; \quad \mathrm{R}^{2}=0.8686$

Overall acceptability: $y=0.1333 \mathrm{x}^{3}-1.5571 \mathrm{x}^{2}+5.2095 \mathrm{x}+1.42 ; \quad \mathrm{R}^{2}=0.7719$

Figure 3: Regression curve of flour/water ratio and softness index of maize tuwo and its sensory quality rating 
The producer using canteen as a selling point could produce for both lunch and dinner as the patronizers (medium-income earners) were available within these periods. Consumption of maize tuwo in a canteen is a reflection of their socio-economic status. Maize tuwo, to a significant extent, can be regarded as a street food because its mode of sale, particularly in urban centres in Nigeria, satisfies the definition of the term which describes street foods as a wide range of ready-to-eat foods and beverages sold and sometimes prepared in public places, notably streets [23].

The quality factors for assessing maize tuwo are colour (white to creamy), texture (ease of mouldability and swallowability) and pleasant taste (cooked maizy taste) and any deviation in these quality attributes of the product is therefore regarded as a deviation from an acceptable quality standard of the product. However, the commercial producers of maize tuwo or producers at household level seem handicapped in controlling the textural quality attribute of the product as the quality and general acceptability of a cereal product was reported to be influenced by the physical and chemical properties of the cereal from which it is produced [10].

\section{Maize flour and tuwo preparation procedures}

The general adoption of grit non-soaking method by all the commercial tuwo producers in the production of their respective flours could be attributed to the extra labour involved in the method coupled with an elongated production period. However, it is generally believed that maize flour obtained from the grit soaking method is whiter than that from grit non-soaking counterpart and is capable of giving whiter maize tuwo. The soaking step in grit soaking method is also believed to improve the textural characteristics of tuwo prepared from such flour particularly in the enhancement of its mouldability. Therefore, the existence of different flour production techniques is another critical area that may have a potential influence on the quality of maize tuwo as it has been observed that different milling methods could affect flour quality and food products derived from such flour [24].

The production of maize tuwo whether commercially or at household level was observed to be an art. The addition or mixing of various components in the course of preparation was not standardized and so one needs to learn the preparation procedure from those people who have already mastered the art. The quantity of maize flour involved in tuwo preparation is usually relative to the quantity of water to be used in order to obtain an acceptable product quality. The addition of an appropriate quantity of flour to the cooking pap-like consistency coupled with a vigorous stirring was observed to be by experience and the precaution was always not to add more flour than required while under-mixing could easily be corrected. Proper cooking of tuwo in the course of its preparation is important as it is believed that this would make the starch component to gelatinize properly thereby make the food product to lose its flour-like taste and assume a new taste of well-cooked and acceptable quality.

Moulding is another important aspect of tuwo production in commercial practice as it makes dispensing easier during sale. The moulding is usually done uniformly or nearuniformly at a specific unit price inside the hawking bowl which has been initially

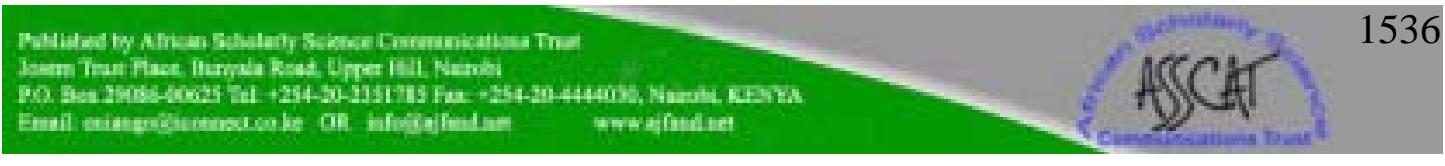


underlaid with a sheet of polythene material meant purposely for covering and preserving the warmth of the food product. It is tuwo in this moulded form (spherical or ball-like shape) that is being sold commercially through hawking. Sale of tuwo through canteen does not usually involve pre-moulding as the food product is normally dispensed into the serving plates from the main chunk placed in the dispensing bowl. The ultimate consumption of tuwo is usually with any of the local vegetable soups (kubewa, kuka and tafshe) as a side dish with or without meat and this normally serves as a source of additional nutrients such as protein, minerals and vitamins. The non-standardization of the preparation procedures for maize tuwo production is therefore a critical area that may have a potential influence on the quality characteristics of the food product.

\section{Particle size distribution of maize flour and colour indices of flour and tuwo}

The variation in the particle sizes of maize flour samples obtained from various maize tuwo producers is another critical area of the production process that may have a potential influence on the quality attributes of maize tuwo. It has been observed that particle size of flour usually plays an important technological role in food processing as it can influence the ease of dispersion in water, degree of surface area availability for a reaction and the quality attributes of the food products derived from such flour $[25]$.

The chroma, C-value, as a parameter in colour measurement, is essentially a measure of colour purity and the higher the value, the greater the colour purity of a given sample [26]. Similarly, the hue angle $\left(h^{\circ}\right)$ is a measure of angular deviation of a sample colour from the three primary colours of red, yellow and green [16]. There was a variation in the hue angle $\left(h^{\circ}\right)$ for maize flour and tuwo respectively. The hue angle shifting from $0^{\circ}$ to $90^{\circ}$ connotes a colour change from red to yellow while a shift from $90^{\circ}$ to $180^{\circ}$ connotes a colour change from yellow to green. However, the hue angle $\left(\mathrm{h}^{\mathrm{o}}\right)$ seems not to be a useful indicator for describing the colour change in maize tuwo processing as red-yellow-green colour indices are seldom applicable. Therefore, the colour indices of both flour and tuwo samples indicate that the conversion of maize flour to tuwo has a strong tendency of reducing the degree of lightness ( $\mathrm{L}^{*}$-value) and colour purity (C-value). Since it has earlier been stated that the colour of maize tuwo is one of the factors being used for the product acceptability assessment, it implies that the variation in the colour indices of maize flour and tuwo samples is another critical area that needs to be attended to when embarking on a technological improvement effort for tuwo quality.

\section{Microbial status and textural quality of commercial maize tuwo}

The microbial status of commercial maize tuwo samples may be influenced by the post-production level of hygiene of the producers and the hawkers, the sanitary state of the materials involved in the sale of the product such as the hawking bowl, and the degree of sanitation of the environment in which the sale is taking place. The observed microbial contamination in maize tuwo is essentially corroborating the earlier observations made that the street foods, to which maize tuwo can be 
categorized particularly in urban centres in Nigeria, are prone to microbiological contamination [27].

The reduction in the softness index of commercial maize tuwo samples under ambient storage condition is directly related to the gradual increase in the degree of firmness of the product as experienced during sale. This may be attributed to retrogradation and re-ordering processes of starch molecules, especially amylose, which affects the overall product textural quality [28, 29]. The softness index of maize tuwo, in practical sense, is a reflection of the force required to compress the food product between the tongue and palate [30]. This is because maize tuwo, like many other traditional food gels or dumplings, is not to be masticated or chewed but swallowed. Chewiness is essentially a consequential response to the degree of product hardness at the point of consumption, which is not required in maize tuwo. The lower softness index value can predispose the food product towards being masticated or chewed. Therefore, the softness level of maize tuwo at the point of consumption is another critical factor with an ability of influencing the acceptability of the food product.

\section{Standardization of ingredient utilization for the production of maize tuwo}

The variations in the ratios of flour to water in tuwo preparation is a reflection of nonstandardization of ingredient utilization in the preparation procedure which may also lead to variation in the quality attributes of the final product. Therefore, the overall flour/water ratio adopted as a working standard in maize tuwo preparation was 1:3.5 since it gave the most acceptable product quality attributes. Similarly, the average values of flour and water used in the sequential mixing during tuwo preparation were subsequently adopted as a working standard of ingredient utilization; and these include initial slurry preparation (20 and $25 \%$ of desired total flour and water, respectively), water used in initial boiling ( $60 \%$ of total), flour added to the pap-like consistency ( $80 \%$ of total) and water added to the gel-like consistency (15\% of total).

\section{CONCLUSION}

The study on the traditional methods of maize tuwo production had revealed certain fundamental characteristics of the production process which might serve as a basis for any technological improvement effort on the product quality. These include the involvement of different market maize varieties and flour preparation techniques requiring proper evaluation for preference. Others include variations in the flour particle size, colour indices of flour and tuwo and softness indexes of the product requiring standardization. All these identified critical areas have strong potentials of influencing the overall product quality and therefore would serve as a useful basis in the quest for improving the quality attributes (colour, texture [mouldability and swallowability] and pleasant taste) of maize tuwo. 


DFFAMDU:

Table 1: General information on the commercial production process of maize tuwo

\begin{tabular}{|c|c|c|c|c|c|}
\hline $\begin{array}{l}\text { Location of commercial } \\
\text { producers of maize } t u w o\end{array}$ & $\begin{array}{l}\text { Type of maize grain } \\
\text { and variety }\end{array}$ & $\begin{array}{l}\text { Sale's } \\
\text { outlet }\end{array}$ & $\begin{array}{l}\text { Quality factor for assessing } \\
\text { maize tuwo }\end{array}$ & $\begin{array}{l}\text { Period of } \\
\text { consumption }\end{array}$ & $\begin{array}{l}\text { Method of flour } \\
\text { production }\end{array}$ \\
\hline Producer I (Akure) & $\begin{array}{l}\text { White maize } \\
\text { (Killa variety) }\end{array}$ & Hawking & $\begin{array}{l}\text { i) Colour (white to creamy) } \\
\text { ii) Texture (ease of } \\
\text { mouldability and } \\
\text { swallowability) } \\
\text { iii) Pleasant taste }\end{array}$ & Lunch & $\begin{array}{l}\text { Grit non-soaking } \\
\text { method }\end{array}$ \\
\hline Producer II (Ojoo-Ibadan) & $\begin{array}{l}\text { White maize } \\
\text { (Agbado-oko } \\
\text { variety) }\end{array}$ & Hawking & $\begin{array}{l}\text { i) Colour (white to creamy) } \\
\text { ii) Texture (ease of } \\
\text { mouldability and } \\
\text { swallowability) } \\
\text { iii) Pleasant taste }\end{array}$ & Lunch & $\begin{array}{l}\text { Grit non-soaking } \\
\text { method }\end{array}$ \\
\hline Producer III (Saabo-Ibadan1) & $\begin{array}{l}\text { White maize } \\
\text { (Shagari variety) }\end{array}$ & Canteen & $\begin{array}{l}\text { i) Colour (white to creamy) } \\
\text { ii) Texture (ease of } \\
\text { mouldability and } \\
\text { swallowability) } \\
\text { iii) Pleasant taste }\end{array}$ & Lunch/Dinner & $\begin{array}{l}\text { Grit non-soaking } \\
\text { method }\end{array}$ \\
\hline Producer IV (Saabo-Ibadan2) & $\begin{array}{l}\text { White maize } \\
\text { (Shagari variety) }\end{array}$ & Hawking & $\begin{array}{l}\text { i) Colour (white to creamy) } \\
\text { ii) Texture (ease of } \\
\text { mouldability and } \\
\text { swallowability) } \\
\text { iii) Pleasant taste }\end{array}$ & Lunch & $\begin{array}{l}\text { Grit non-soaking } \\
\text { method }\end{array}$ \\
\hline
\end{tabular}




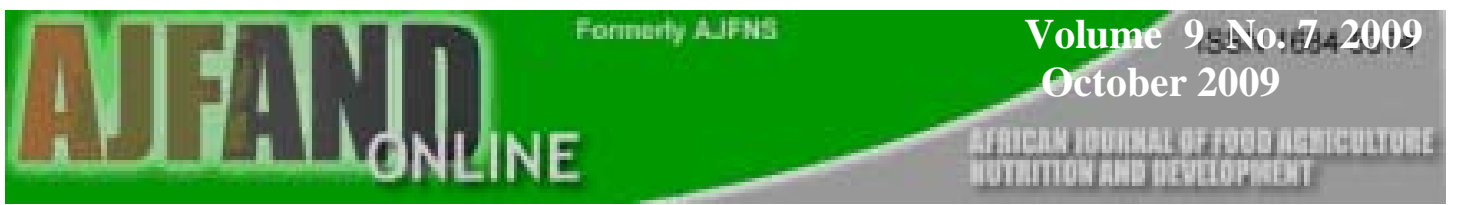

Table 2: Particle size distribution of flour and colour indices of flour and tuwo samples

\begin{tabular}{|c|c|c|c|c|c|c|c|c|c|c|c|c|c|}
\hline \multirow{3}{*}{$\begin{array}{l}\text { Maize tuwo } \\
\text { producer }\end{array}$} & \multicolumn{3}{|c|}{ Particle size distribution of flour $^{1}$} & \multicolumn{10}{|c|}{ Colour measurement $^{2}$} \\
\hline & \multirow{2}{*}{$\begin{array}{l}\text { Sieve } \\
\operatorname{size}(\mu \mathrm{m})\end{array}$} & \multirow{2}{*}{$\begin{array}{l}\text { Mass of } \\
\text { flour } \\
\text { retained (g) }\end{array}$} & \multirow{2}{*}{$\begin{array}{l}\% \text { Mass } \\
\text { retained }\end{array}$} & \multicolumn{5}{|c|}{ Maize flour } & \multicolumn{5}{|c|}{ Maize tuwo } \\
\hline & & & & $\mathrm{L}^{*}$ & $a^{*}$ & $b^{*}$ & $\begin{array}{l}\text { Chrom } \\
\text { a, C }\end{array}$ & $\begin{array}{l}\text { Hue } \\
\text { angle, } \\
\mathrm{h}^{\mathrm{o}}\end{array}$ & $\mathrm{L}^{*}$ & $a^{*}$ & $b^{*}$ & $\begin{array}{l}\text { Chrom } \\
\text { a, C }\end{array}$ & $\begin{array}{l}\text { Hue } \\
\text { angle, } \\
\mathrm{h}^{\mathrm{o}}\end{array}$ \\
\hline \multirow{5}{*}{$\begin{array}{l}\text { Producer I } \\
\text { (Akure) }\end{array}$} & 850 & 4.70 & 1.9 & \multirow{5}{*}{$\begin{array}{l}88.6 \\
\pm 0.15^{\mathrm{ab}}\end{array}$} & \multirow{5}{*}{$\begin{array}{l}-0.07 \\
\pm 0.02^{\mathrm{a}}\end{array}$} & \multirow{5}{*}{$\begin{array}{l}15 \\
\pm 0.21^{\mathrm{a}}\end{array}$} & \multirow{5}{*}{$\begin{array}{l}15 \\
\pm 0.21^{\mathrm{a}}\end{array}$} & \multirow{5}{*}{$\begin{array}{l}90.3 \\
\pm 0.07^{d}\end{array}$} & \multirow{5}{*}{$\begin{array}{l}67 \\
\pm 0.42^{\mathrm{cd}}\end{array}$} & \multirow{5}{*}{$\begin{array}{l}-1.53 \\
\pm 0.33^{b}\end{array}$} & \multirow{5}{*}{$\begin{array}{l}8.6 \\
\pm 0.32^{\mathrm{e}}\end{array}$} & \multirow{5}{*}{$\begin{array}{l}8.8 \\
\pm 0.25^{\mathrm{e}}\end{array}$} & \multirow{5}{*}{$\begin{array}{l}100.1 \\
\pm 2.49^{b c}\end{array}$} \\
\hline & 425 & 51.92 & 20.8 & & & & & & & & & & \\
\hline & 300 & 79.23 & 31.7 & & & & & & & & & & \\
\hline & 150 & 58.54 & 23.4 & & & & & & & & & & \\
\hline & 63 & 33.11 & 13.2 & & & & & & & & & & \\
\hline \multirow{5}{*}{$\begin{array}{l}\text { Producer II (Ojoo- } \\
\text { Ibadan) }\end{array}$} & 850 & 3.50 & 1.4 & \multirow{5}{*}{$\begin{array}{l}88.2 \\
\pm 0.21^{b}\end{array}$} & \multirow{5}{*}{$\begin{array}{l}-0.10 \\
\pm 0.04^{\mathrm{a}}\end{array}$} & \multirow{5}{*}{$\begin{array}{l}14.9 \\
\pm 0.18^{\mathrm{a}}\end{array}$} & \multirow{5}{*}{$\begin{array}{l}14.9 \\
\pm 0.18^{\mathrm{a}}\end{array}$} & \multirow{5}{*}{$\begin{array}{l}90.4 \\
\pm 0.16^{\mathrm{d}}\end{array}$} & \multirow{5}{*}{$\begin{array}{l}66.6 \\
\pm 0.35^{\mathrm{d}}\end{array}$} & \multirow{5}{*}{$\begin{array}{l}-1.98 \\
\pm 0.28^{c}\end{array}$} & \multirow{5}{*}{$\begin{array}{l}8.3 \\
\pm 0.29^{\mathrm{e}}\end{array}$} & \multirow{5}{*}{$\begin{array}{l}8.6 \\
\pm 0.22^{\mathrm{e}}\end{array}$} & \multirow{5}{*}{$\begin{array}{l}103.4 \\
\pm 2.27^{\mathrm{a}}\end{array}$} \\
\hline & 425 & 43.43 & 17.4 & & & & & & & & & & \\
\hline & 300 & 85.12 & 34.1 & & & & & & & & & & \\
\hline & 150 & 66.35 & 26.5 & & & & & & & & & & \\
\hline & 63 & 31.18 & 12.5 & & & & & & & & & & \\
\hline \multirow{5}{*}{$\begin{array}{l}\text { Producer III } \\
\text { (Saabo-Ibadan1) }\end{array}$} & 850 & 3.10 & 1.2 & \multirow{5}{*}{$\begin{array}{l}88.4 \\
\pm 0.32^{\mathrm{ab}}\end{array}$} & \multirow{5}{*}{$\begin{array}{l}-0.12 \\
\pm 0.02^{\mathrm{a}}\end{array}$} & 13.3 & 13.3 & 90.5 & 66.8 & -1.82 & 8.4 & 8.6 & 102.1 \\
\hline & 425 & 46.25 & 18.5 & & & $\pm 0.19^{c}$ & $\pm 0.19^{c}$ & $\pm 0.08^{\mathrm{d}}$ & $\pm 0.37^{\mathrm{d}}$ & $\pm 0.34^{\mathrm{bc}}$ & $\pm 0.18^{\mathrm{e}}$ & $\pm 0.25^{\mathrm{e}}$ & $\pm 1.95^{\mathrm{ab}}$ \\
\hline & 300 & 90.22 & 36.1 & & & & & & & & & & \\
\hline & 150 & 60.43 & 24.2 & & & & & & & & & & \\
\hline & 63 & 32.47 & 13 & & & & & & & & & & \\
\hline
\end{tabular}

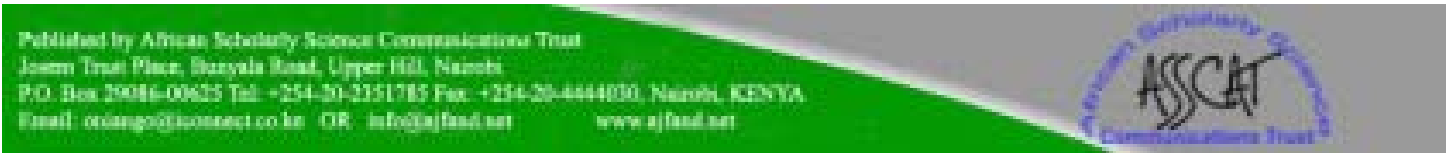




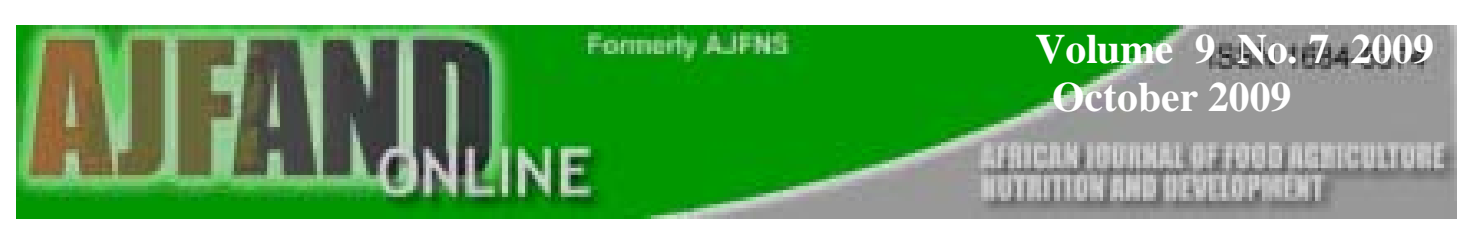

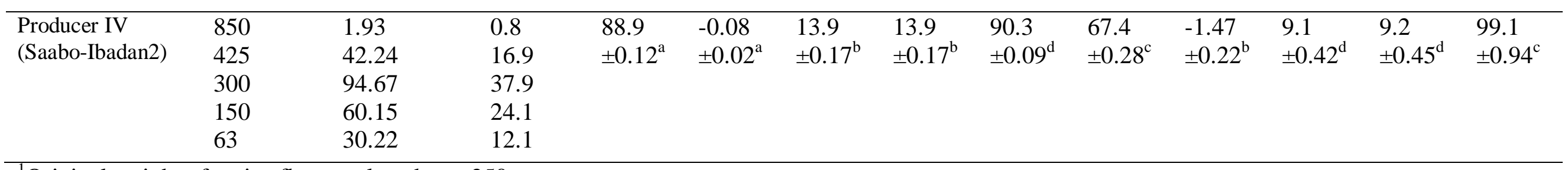

${ }^{1}$ Original weight of maize flour analyzed was $250 \mathrm{~g}$.

${ }^{2}$ Mean values within the same column having the same superscript are not significantly different at $\mathrm{P}<0.05$.

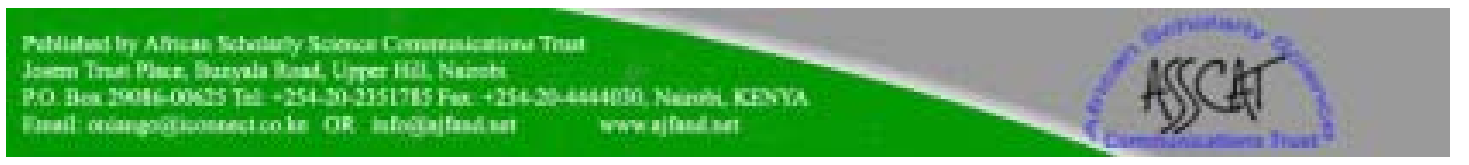


Table 3: Microbial status and softness index of commercial maize tuwo

\begin{tabular}{|c|c|c|c|c|}
\hline \multirow[t]{2}{*}{ Maize tuwo source } & \multicolumn{2}{|c|}{$\begin{array}{l}\text { Microbial status of maize tuwo } \\
\text { about } 9 \mathrm{hr} \text { after production }\end{array}$} & \multicolumn{2}{|c|}{ Softness index $(\mathrm{mm})^{\mathrm{a}}$} \\
\hline & $\begin{array}{l}\text { Bacterial count } \\
\text { (cfu/g) }\end{array}$ & $\begin{array}{l}\text { Fungal count } \\
(\mathrm{sfu} / \mathrm{g})\end{array}$ & $\begin{array}{l}\text { Immediately } \\
\text { after cooling }\end{array}$ & $\begin{array}{l}\text { About } 9 \mathrm{hr} \text { after } \\
\text { production }\end{array}$ \\
\hline Producer I (Akure) & $8.0 \times 10^{4}$ & $1.0 \times 10^{2}$ & $17.8 \pm 0.1^{b}$ & $16.2 \pm 0.1^{\mathrm{d}}$ \\
\hline $\begin{array}{l}\text { Producer II (Ojoo- } \\
\text { Ibadan) }\end{array}$ & $1.0 \times 10^{4}$ & Nil & $18.5 \pm 0.2^{\mathrm{a}}$ & $17.1 \pm 0.2^{b}$ \\
\hline $\begin{array}{l}\text { Producer III (Saabo- } \\
\text { Ibadan1) }\end{array}$ & $3.0 \times 10^{4}$ & Nil & $18.7 \pm 0.3^{\mathrm{a}}$ & $16.7 \pm 0.1^{\mathrm{c}}$ \\
\hline $\begin{array}{l}\text { Producer IV (Saabo- } \\
\text { Ibadan2) }\end{array}$ & $5.0 \times 10^{4}$ & Nil & $18.3 \pm 0.2^{\mathrm{a}}$ & $17.5 \pm 0.2^{\mathrm{a}}$ \\
\hline
\end{tabular}

${ }^{\mathrm{a}}$ Mean value of softness index followed by different superscript in the column are significantly different from one another at $\mathrm{P}<0.05$. 


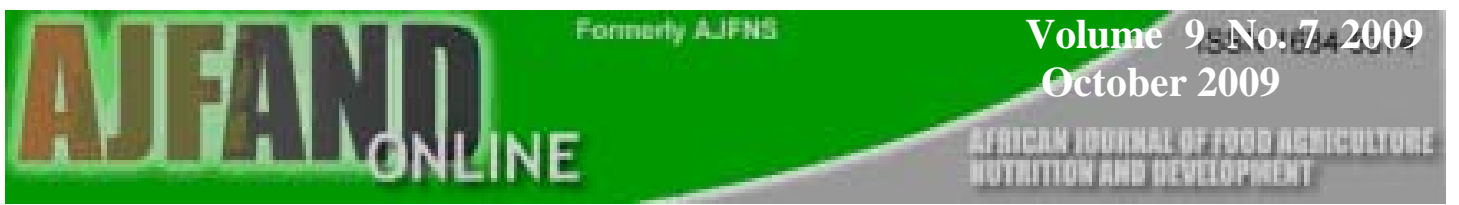

Table 4: Flour and water usage in maize tuwo preparation

\begin{tabular}{|c|c|c|c|c|c|c|c|c|c|c|}
\hline \multirow[t]{3}{*}{$\mathrm{S} / \mathrm{N}$} & \multirow[t]{3}{*}{ Ingredient/Processing steps } & \multicolumn{8}{|c|}{ Tuwo source } & \multirow{3}{*}{$\begin{array}{l}\text { Approximate } \\
\text { average value } \\
(\%)\end{array}$} \\
\hline & & \multicolumn{2}{|c|}{ Producer I (Akure) } & \multicolumn{2}{|c|}{$\begin{array}{l}\text { Producer } \\
\text { Ibadan) }\end{array}$} & \multicolumn{2}{|c|}{$\begin{array}{l}\text { Producer III } \\
\text { (Saabo-Ibadan1) }\end{array}$} & \multicolumn{2}{|c|}{$\begin{array}{l}\text { Producer IV (Saabo- } \\
\text { Ibadan2) }\end{array}$} & \\
\hline & & Quantity & $(\%)$ & Quantity & $(\%)$ & Quantity & $(\%)$ & Quantity & $(\%)$ & \\
\hline \multirow[t]{4}{*}{ (a) } & ${ }^{\mathrm{a}}$ Flour $(\mathrm{g})$ : & & & & & & & & & \\
\hline & Flour used in slurry preparation & 282.9 & 19.2 & 312.4 & 20.8 & 328.3 & 22 & 287.9 & 19 & 20 \\
\hline & $\begin{array}{l}\text { Flour added to the pap-like } \\
\text { consistency }\end{array}$ & 1187.3 & 80.8 & 1189.3 & 79.2 & 1164.7 & 78 & 1226.3 & 81 & 80 \\
\hline & Total flour used & 1470.2 & 100 & 1501.7 & 100 & 1493.0 & 100 & 1514.2 & 100 & 100 \\
\hline \multirow[t]{5}{*}{ (b) } & Water $(\mathrm{ml}):$ & & & & & & & & & \\
\hline & Water used in slurry preparation & 1193.9 & 24.6 & 1334.1 & 25.1 & 1258.6 & 24.9 & 1398.6 & 24.3 & 25 \\
\hline & Water used in initial boiling & 2863.4 & 59 & 3295.5 & 62 & 2993.3 & 59.2 & 3440.9 & 59.8 & 60 \\
\hline & $\begin{array}{l}\text { Water added to the gel-like } \\
\text { consistency }\end{array}$ & 796.1 & 16.4 & 685.7 & 12.9 & 802.2 & 15.9 & 910.7 & 15.8 & 15 \\
\hline & Total water used & 4853.3 & 100 & 5315.3 & 100 & 5054.1 & 100 & 5750.2 & 100 & 100 \\
\hline (c) & $\begin{array}{l}\text { Ratio of total flour/ total water } \\
\text { used }\end{array}$ & $1: 3.3$ & & $1: 3.5$ & & $1: 3.4$ & & $1: 3.8$ & & -- \\
\hline (d) & Total cooking time $(\mathrm{min})$ & 30 & & 32 & & 31.5 & & 33 & & 32 \\
\hline
\end{tabular}

${ }^{\mathrm{a}}$ Moisture content of flour used $=9.2 \%$ 
Table 5: Sensory quality rating and softness index of maize tuwo prepared from different overall flour/water ratios ${ }^{1}$

\begin{tabular}{|c|c|c|c|c|c|c|c|}
\hline \multirow{2}{*}{$\begin{array}{l}\text { Tuwo } \\
\text { sample }\end{array}$} & \multirow{2}{*}{$\begin{array}{l}\text { Overall } \\
\text { flour/water } \\
\text { ratio }\end{array}$} & \multicolumn{5}{|c|}{ Sensory factor } & \multirow{2}{*}{$\begin{array}{l}\text { Softness } \\
\text { index } \\
(\mathrm{mm})\end{array}$} \\
\hline & & Colour & $\begin{array}{l}\text { Texture } \\
\text { (mouldability) }\end{array}$ & Aroma & Taste & $\begin{array}{l}\text { Overall } \\
\text { Acceptability }\end{array}$ & \\
\hline Sample I & $1: 3.1$ & $6.6^{b}$ & $4.3^{\mathrm{c}}$ & $6.2^{b}$ & $6.2^{c}$ & $5.3^{\mathrm{c}}$ & $15.3 \pm 0.1^{\mathrm{e}}$ \\
\hline Sample II & $1: 3.3$ & $6.9^{\mathrm{a}}$ & $6.9^{\mathrm{a}}$ & $6.3^{\mathrm{b}}$ & $6.7^{\mathrm{b}}$ & $6.3^{\mathrm{b}}$ & $16.2 \pm 0.1^{d}$ \\
\hline Sample III & $1: 3.5$ & $6.9^{\mathrm{a}}$ & $7.1^{\mathrm{a}}$ & $7.1^{\mathrm{a}}$ & $7.3^{\mathrm{a}}$ & $7.2^{\mathrm{a}}$ & $16.9 \pm 0.2^{c}$ \\
\hline Sample IV & $1: 3.7$ & $6.6^{\mathrm{b}}$ & $4.8^{\mathrm{b}}$ & $6.3^{\mathrm{b}}$ & $5.8^{\mathrm{d}}$ & $5.5^{\mathrm{c}}$ & $17.9 \pm 0.2^{b}$ \\
\hline Sample V & $1: 3.9$ & $6.8^{\mathrm{ab}}$ & $4.5^{\mathrm{bc}}$ & $6.3^{\mathrm{b}}$ & $5.1^{\mathrm{e}}$ & $5.3^{\mathrm{c}}$ & $19.1 \pm 0.3^{\mathrm{a}}$ \\
\hline
\end{tabular}

${ }^{\mathrm{I}}$ Mean values within the same column having the same superscript are not significantly different at $\mathrm{P}<0.05$ 


\section{REFERENCES}

1. Kent NL and AD Evers Technology of Cereals: An Introduction for Students of Food Science and Agriculture. Oxford, Elsevier, 1994.

2. Mejia D Maize: postharvest operations. In: Mejia D and E Parrucci (Eds). Postharvest compendium. Rome: FAO, 2005: Available online at: http://www.fao.org/inpho/ . Accessed on December 10, 2006.

3. Muller HG Traditional cereal processing in Nigeria and Ghana. Ghana J. Agric. Sci. 1970; 3: 187-195.

4. Oke OL and IA Adeyemi Consumption of alternative flours in West Africa. A paper presented at the $8^{\text {th }}$ World Congress of Food Science and Technology, Toronto, Canada, September 29- October 4, 1991.

5. Okoruwa AE Utilization and Processing of Maize. IITA Research Guide No. 35. IITA, Ibadan, 1997.

6. Vonortas NS Building competitive firms: technology policy initiatives in Latin America. Technol. Soc. 2002; 24: 433 - 459.

7. King DR and ML Nowack The impact of government policy on technology transfer: an aircraft industry case study. J. Eng. Technol. Manage. 2003; 20: 303-318.

8. Kordylas JM Processing and Preservation of Tropical and Sub-tropical Foods. Macmillan, London, 1990.

9. Bolade MK, Usman MA, Rasheed AA, Benson EL and I Salifou Influence of hydrothermal treatment of maize grains on the quality and acceptability of tuwon masara (traditional maize gel). Food Chem. 2002; 79: 479-483.

10. Akingbala JO, Oguntimein GB and AO Sobande Physiochemical properties and acceptability of yam flour substituted with soyflour. Plant Foods Hum. Nutr. 1995; 48: 73-80.

11. Hermansson AM and K Svegmark Developments in the understanding of starch functionality. Trends Food Sci.Tech. 1996; 7: 345-353.

12. Taiwo KA, Irefin IA and MO Ilori Integration of modern technologies in traditional food processing in Nigeria. Food Rev. Int. 1997; 13: 611-621.

13. Oluwamukomi MO, Eleyinmi AF and VN Enujiugha Effect of soy supplementation and its stage of inclusion on the quality of ogi - a fermented maize meal. Food Chem. 2005; 91: 651-657. 
14. Bolade MK and MS Buraimo Textural and sensory quality enhancement of sorghum tuwo. Int. J. Food Sci. Tech. 2006; 41:115-123.

15. McGuire RG Reporting of objective color measurement. HortScience 1992; 27: 1254-1255.

16. Francis FJ Colour Analysis. In: Nielsen SS (Ed). Food Analysis. Aspen Publishers, New York, 1998.

17. Diebel $\mathbf{K}$ and $\mathbf{K}$ Swanson Cereal and cereal products. In: FP Downes and K Ito (Eds). Compendium of Methods for the Microbiological Examination of Foods and Technology. 2001.

18. Larmond E Laboratory Methods for Sensory Evaluation of Foods. Publication No. 1673. Department of Agriculture, Ottawa, Canada, 1977.

19. IFT. Sensory evaluation guide for testing food and beverage products. Food Technol. 1981; 35: 50-59.

20. Iken JE and NA Amusa Maize research and production in Nigeria. Afr. $J$. Biotechnol. 2004; 3: 302-307.

21. Iwuoha CI Comparative evaluation of physicochemical qualities of flours from steam-processed yam tubers. Food Chem. 2004; 85: 541-551.

22. Hardacre AK and SM Clark The effect of hybrid and growing environment on the rheological properties of starch and flour from maize (Zea mays L.) grain dried at four temperatures. Int. J. Food Sci. Tech. 2006; 41: 144-150.

23. Winarno FG and A Allain Street foods in developing countries: lessons from

Asia. Rome: FAO, 1991: Available online at: http://www.fao.org/docrep/w3550t. . Accessed on December 10, 2006.

24. Lijuan S, Guiying Z, Guoan $\mathbf{Z}$ and $\mathbf{L}$ Zaigui Effects of different milling methods on flour quality and performance in steamed bread making. J. Cereal Sci. 2007; 45: 18-23.

25. Wang $\mathbf{L}$ and RA Flores Effects of flour particle size on the textural properties of flour Tortillas. J. Cereal Sci. 2000; 31: 263 - 272.

26. deMan JM Principles of Food Chemistry. Van Nostrand Reinhold, New York. 1990: 40 - 120.

27. Cardinale E, Perrier GJD, Tall F, Gueye EF and G Salvat Risk factors for contamination of ready-to-eat street-vended poultry dishes in Dakar, Senegal. Int. J. Food Microbiol. 2005; 103: 157-165. 
28. Hodge JE and EM Osman Carbohydrates. In: Fennema OR (Ed). Principles of Food Science, Part I, Food Chemistry. New York: Marcel Dekker, 1976: 41138.

29. Ragaee S and EM Abdel-Aal Pasting properties of starch and protein in selected cereals and quality of their food products. Food Chem. 2006; 95: 9-18.

30. Szczesniak AS Texture is a sensory property. Food Qual. Prefer. 2002; 13: 215-225. 